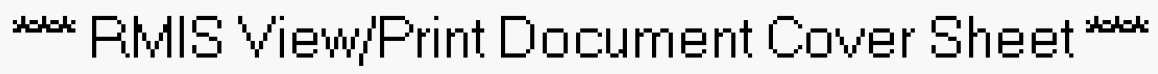

This document was retrieved from the Boeing ISEARCH System.

Accession \#: D196071728

Document \#: SD-WM-RPT-192

Title/Desc:

REMOTE CHARACTERIZATION OF MIXED WASTE BY INFRARED SPECTROSCOPY FY1995 REPORT 


2. To: (Receiving Organization)
Distribution

5. Proj./Prog./Dept./Div.:

TWRS Safety Basis

8. Originator Remarks:

This document WHC-SD-WM-RPT-192 is for the Remote

Characterization of Mixed Waste by Infrared Spectroscopy

11. Receiver Remarks:
3. From: (originating Organization) TWRS Safety Basis

6. Cog. Engr.:

T. V. Rebagay

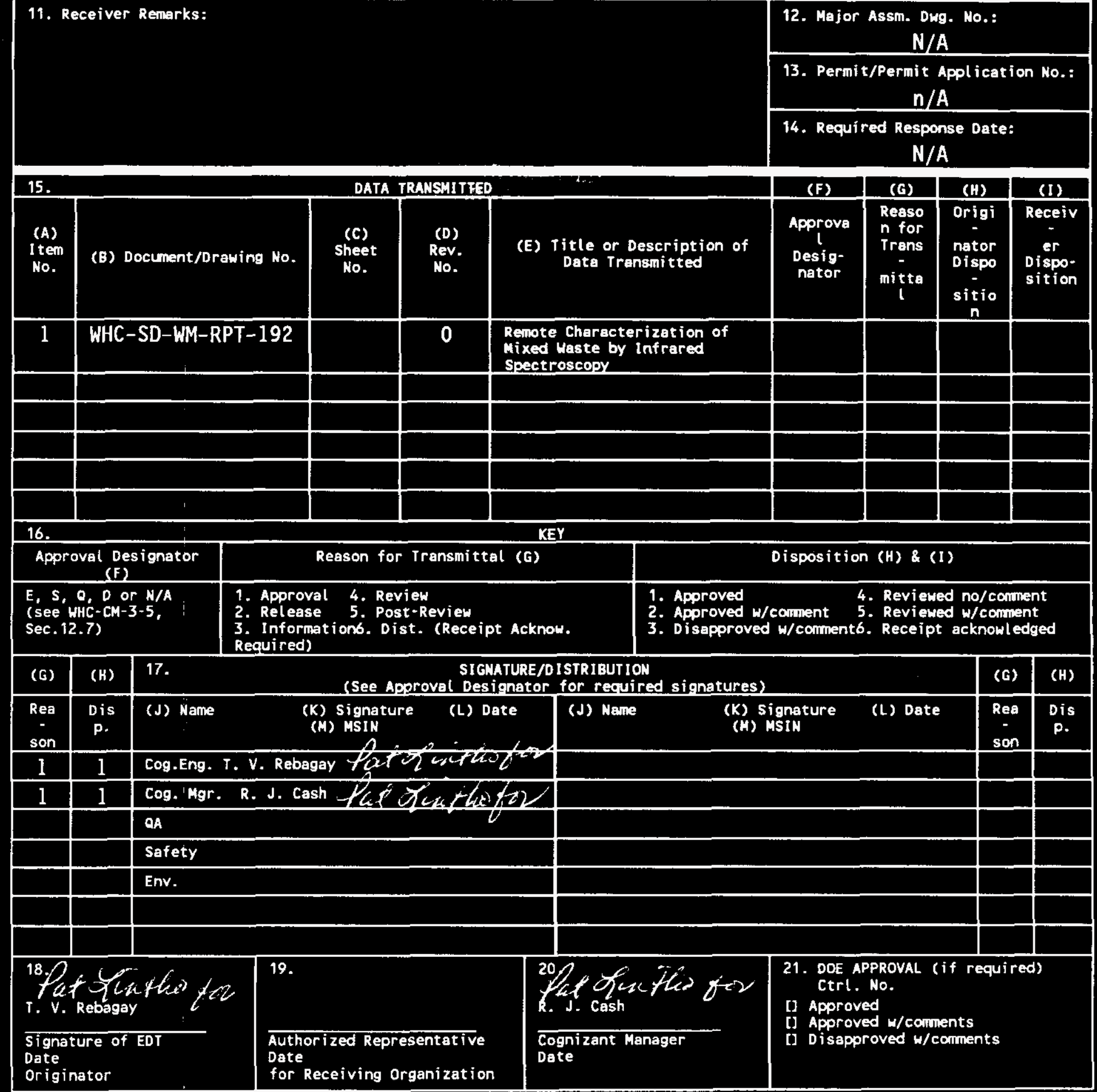




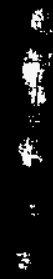

TEIS PAGD IVIENIIONALIY IMFT BIANK

\$2

 


\section{RELEASE AUTHORIZATION}

Document Number: WHC-SD-WM-ATR-192, REV 0

Document Title: $\quad$ Remote Characterization of Mixed Waste by Infrared Spectroscopy

Release Date: $\quad 10 / 3 / 95$

This document was reviewed following the procedures described in WHC-CM-3-4 and is:

APPROVED FOR PUBLIC RELEASE

WHC Information Release Administration Specialist:

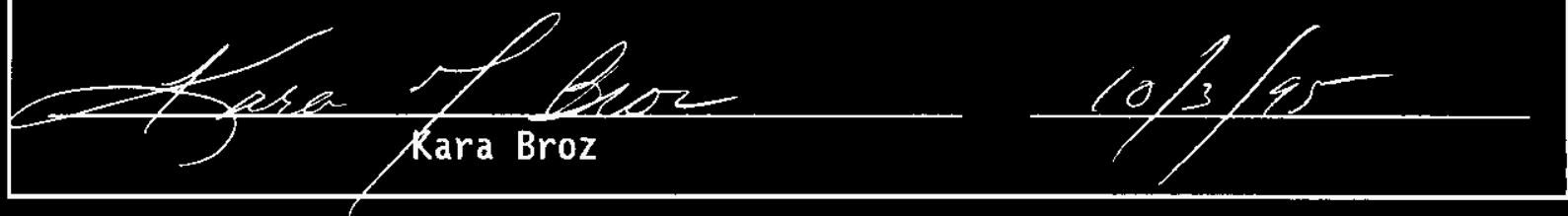

TRADEMARK DISCLAIMER. Reference herein to any specific commercial product, process, or service by trade name, trademark, manufacturer, or otherwise, does not necessarily constitute or imply its endorsement, recommendation, or favoring by the United States Government or any agency thereof or its contractors or subcontractors.

This report has been reproduced from the best available copy. Available in paper copy. Printed in the United States of America. To obtain copies of this report, contact:

Westinghouse Hanford Company - Document Control Services

P.0. Box 1970, Mailstop H6-08, Richland, WA 99352

Telephone: (509) 372-2420; Fax: (509) 376-4989 
TEETS PAGB INIENTIONALLY IOTI BLANK 


2. Title
Remote Characterization of Mixed Waste by Infrared
Spectroscopy - Fiscal Year 1995 Report

5. Key Words

Infrared, Spectroscopy, Moisture, Characterization, Waste, Hot Cel1, Fiber Optic
3. Number

WHC-SD-WM-RPT-192
4. Rev No.

0
6. Author

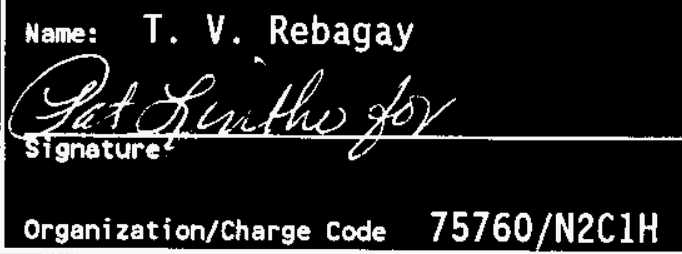

\section{Abstract}

This report summarizes development work completed in FY 1995 on near-infrared (NIR) and Fourier Transform Infrared (FTIR) spectroscopy for determining the moisture content and solid species present in Hanford Site high-level waste. In prior fiscal years, the main emphasis was on identification of cyanide species that might be present in the ferrocyanide waste tanks, but the present thrust has been more focused on determining the moisture content of the waste. If sufficient moisture is present in the waste, propagating reactions in reactive waste are precluded, regardless of its fuel content. A prototype hot cell NIR moisture probe is now ready for hot cell deployment to sense moisture contents and homogeneity in tank waste samples. 
THIIS PAGE INTENTIONALLY

1. ITHFT BLANK 


\title{
REMOTE CHARACTERIZATION OF MIXED WASTE BY INFRARED \\ SPECTROSCOPY - \\ FISCAL YEAR 1995 REPORT
}

\author{
T. V. Rebagay \\ F. R. Reich \\ D. A. Dodd \\ T. Lopez \\ J. K. Watts \\ R. J. Cash
}

Date Published

September 1995

Prepared for the U.S. Department of Energy

Assistant Secretary for Envirommental Management

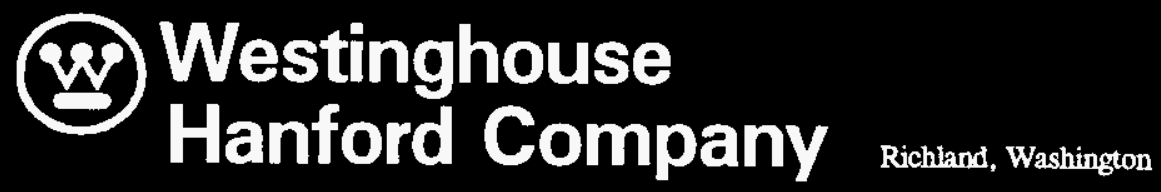

Management and Operations Contractor for the

U.S. Department of Energy under Contract DE-ACO6-87RL10930 
WHC-SD-WM-RPT-192 Rev. 0

This page intentionally left blank. 


\title{
REMOTE CHARACTERIZATION OF MIXED WASTE BY INFRARED SPECTROSCOPY
}

\begin{abstract}
Tank waste characterization requires various analytical systems to identify the chemical composition and water content of Hanford Site high-level waste to ensure that safety and environmental requirements are met and to provide stability and maintain the integrity of the tanks. An analytical database for the waste is also key to the design and implementation of pre-treatment and disposal processes. These tanks contain high-level mixed waste as sludge, saltcake, and supernate.

Diffuse reflectance infrared spectroscopy is a technique frequently used to characterize solid materials. The capability of analyzing complex mixtures such as tank waste (sludges and saltcakes) without modifying the sample is one of the interesting features of this technique. Its simplicity and speed of analysis are also positive aspects.
\end{abstract}

To provide a faster, cheaper, and safer technique to monitor the moisture content of tank waste, two types of near-infrared (NIR) diffuse reflectance fiber optic probes interfaced to a Fourier transform infrared spectrometry system (FTIR) were studied. Lower absorptivities in the (NIR) region enable longer pathlengths to be used leading to easier nondestructive sampling. Both overtone and combination bands of water can be used for moisture measurements. While a previous report (Rebagay et al. 1995) provides evidence for the feasibility of using fiber optic probes, the results reported were strictly qualitative. A hot cell demonstration using this integrated system to quantitatively measure the water content of mixed waste is described in this report.

In seeking a strategy to identify individual species in the waste with minimal sample preparation, a modular transfer optic system equipped with a mid-infrared diffuse reflectance sampler was assessed. Light pipes were used to present the sample to the FTIR spectrometer. Its performance for obtaining rapid, high quality mid-infrared (MIR) spectra of mixed waste is compared with photoacoustic spectroscopy. 
WHC-SD-WM-RPT-192 Rev. 0

This page intentionally left blank. 
WHC-SD-WM-RPT-192 Rev. 0

\section{CONTENTS}

1.0 INTRODUCTION $\ldots \ldots \ldots \ldots \ldots \ldots \ldots \ldots \ldots \ldots \ldots \ldots$

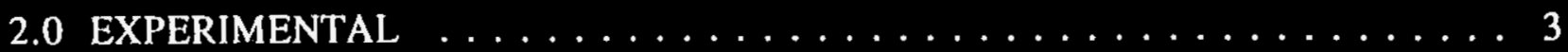

2.1 INSTRUMENTATION $\ldots \ldots \ldots \ldots \ldots \ldots \ldots \ldots \ldots \ldots$

2.2 CALIBRATION OF FIBER OPTIC SYSTEM $\ldots \ldots \ldots \ldots \ldots \ldots \ldots 5$

2.3 MODULAR TRANSFER OPTIC SYSTEM $\ldots \ldots \ldots \ldots \ldots \ldots \ldots$

3.0 RESULTS AND DISCUSSION $\ldots \ldots \ldots \ldots \ldots \ldots \ldots \ldots \ldots$

3.1 SPECTRA OF INDIVIDUAL COMPONENTS OF WASTE $\ldots \ldots \ldots \ldots 7$

3.2 QUANTITATIVE DETERMINATION OF MOISTURE $\ldots \ldots \ldots \ldots \ldots 12$

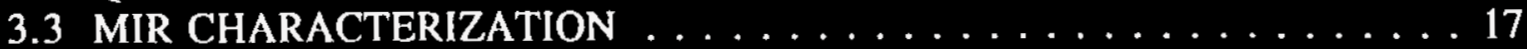

4.0 CONCLUSIONS $\ldots \ldots \ldots \ldots \ldots \ldots \ldots \ldots \ldots \ldots \ldots \ldots \ldots \ldots \ldots \ldots \ldots$

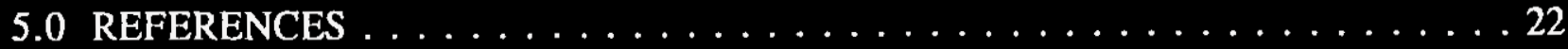




\section{LIST OF FIGURES}

1. Fiber Optic Diffuse Reflectance Probe. . . . . . . . . . . . . . . . 4

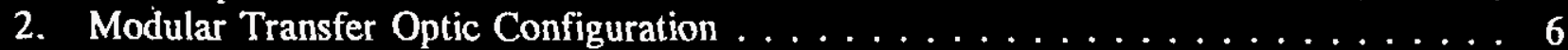

3. NIR Reference Spectra $\ldots \ldots \ldots \ldots \ldots \ldots \ldots \ldots \ldots \ldots \ldots \ldots$

4. NIR Reference Spectra $\ldots \ldots \ldots \ldots \ldots \ldots \ldots \ldots \ldots \ldots \ldots \ldots \ldots$

5. NIR Reference Spectra . . . . . . . . . . . . . . . . 10

6. NIR Reference Spectra . . . . . . . . . . . . . . . . . . . 11

7. NIR Reference Spectra for Three Organic Compounds . . . . . . . . . . . . 13

8. Spectra of Tank Waste with Low Moisture Content . . . . . . . . . . . . 15

9. Spectra of Tank Waste with High Moisture Content $\ldots \ldots \ldots \ldots \ldots$

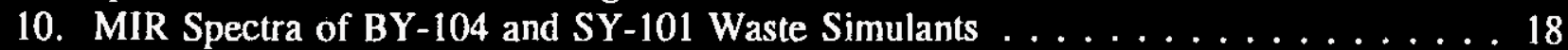

11. MIR Spectra of BY-104 and SY-101 Waste Simulants . . . . . . . . . . . 19

12. Spectra of Tank $\mathrm{C}-107$ Waste . . . . . . . . . . . . . . . . . 20

\section{LIST OF TABLES}

1. Standard Error of Prediction Results $\ldots \ldots \ldots \ldots \ldots \ldots \ldots$ 


\subsection{INTRODUCTION}

The Hanford Site waste tanks contain high-level mixed waste in the form of sludge, saltcake, and supernates. Moisture has been identified as one of the critical parameters that impacts the safety of these tanks, particularly those containing organics and cyanoferrates (Postma et al., 1994). It has been postulated that significant concentrations of fuel (organics and/or cyanoferrates) in contact with oxidizers (nitrates and nitrites) under dry conditions and elevated temperatures could undergo propagating exothermic reactions. Experiments have shown that a tank waste with moisture greater than 17 weight percent (wt \%) and organics less than $5 \mathrm{wt} \%$ regardless of its cyanoferrate content is considered safe (Babad et al. 1995, Fauske et al. 1995). Chemical analyses and moisture measurements are, therefore, necessary to ensure compliance with safety and environmental requirements and to provide stability and maintain the integrity of these tanks.

\subsection{EXPERIMENTAL}

\subsection{INSTRUMENTATION}

A dual-bench Fourier transform infrared (FTIR) spectrometry system (FTS 60A, Bio-Rad Analytical Laboratory, Cambridge, MA) equipped with a quartz beamsplitter and mercurycadmium-telluride (HgCdTe) and indium antimonide ( $\mathrm{nSb}$ ) detectors was used to record all NIR spectra. To provide a faster, cheaper, and safer technique to monitor the moisture content of tank waste (sludges and saltcake), two types of NIR diffuse reflectance fiber optic probes were interfaced to the FTIR spectrometry system. These were (a) a Westinghouse Savannah River Company (WSRC) fiber optic probe and (b) an AXIOM ${ }^{\text {TM }}$ probe (AXIOM Analytical Inc., Irvine, CA). The fiber optic probes served as light conduits to detect analytes via optical changes of properties such as intensity or wavelength.

The WSRC probe is a six-around-one bifurcated probe. Its configuration and operation are described in detail in Rebagay et al. (1995). Briefly, the probe has a common leg and is bifurcated into two legs joined together in a zip cord configuration. The common leg has a center fiber (detector fiber) surrounded by six other fibers (light source fibers). Each fiber has a 400- $\mu \mathrm{m}$ diameter, very low-OH silica core, a 440- $\mu \mathrm{m}$ diameter doped silica cladding, a $470-\mu \mathrm{m}$ polyamide buffer, and a $700-\mu \mathrm{m}$ polymer jacket. The polymer jacket was removed by immersion in acetone and stripped off using a wire stripper. The buffers of the common leg were molded together using an epoxy resin to form a bundle. The terminal at the common end was beveled toward the center fiber and then bonded to a 20 -mil sapphire window.

The schematic design of the AXIOM probe is depicted in Figure 1. The probe consists of a collimator, a hollow metallic light guide, focusing optics, and a sapphire window. A customized standbar/mount was installed at the terminal of the probe to allow reproducible 
positioning and to avoid altering the probe's field of view. A separate bifurcated fiber optic cable (Fiberguide Industries, Stirling, NJ) is attached to the probe terminal. The common leg of the fiber optic cable contains 80 very low-OH fused silica fibers that were then divided randomly to form two legs, each leg consisting of 40 fibers (i.e., 40 fibers to the infrared source and 40 fibers to the detector assembly). Each fiber has a very low-OH pure silica core $(O D=200 \mu \mathrm{m})$, fluorine-doped silica clad $(O D=220 \mu \mathrm{m})$, and a polyamide jacket $(\mathrm{OD}=245 \mu \mathrm{m})$. The numerical aperture of each fiber is 0.26 . The optical diameter of the complete bundle is $2.3 \mathrm{~mm}$ and that of each of the bifurcated legs is $1.6 \mathrm{~mm}$. The fiber cables use standard SMA connectors. These connectors provide a "click-fit" for sampling reproducibility and for fast and easy connection between the fiber bundle and the AXIOM probe.

The complete fiber optic system consists of the FTIR spectrometer, a fiber optic accessory for mounting and positioning the fiber optic cables, the fiber optic probe, the detector, and a micro-mechanical translation stage for the WSRC probe. The stage allows vertical adjustment of the stainless steel sample pan $(3 \mathrm{~mm}$ deep $\times 10 \mathrm{~mm}$ diameter) with a height accuracy of better than $10 \mu \mathrm{m}$.

Figure 1. Fiber Optic Diffuse Reflectance Probe.

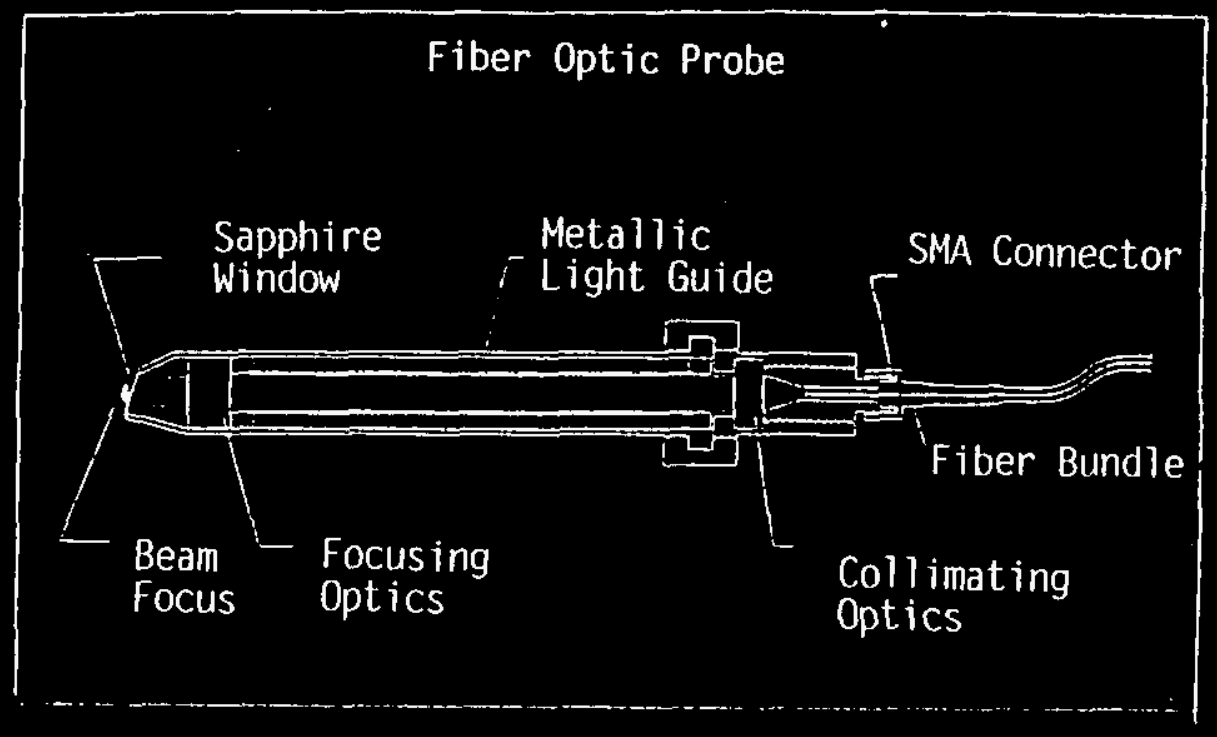




\subsection{CALIBRATION OF FIBER OPTIC SYSTEM}

The calibration of the fiber optic probes was performed using simulated nonradioactive waste mimicking the actual composition of waste tank waste (Jeppson and Wong 1993). Simulants with water contents ranging from 0 to $35 \mathrm{wt} \%$ were prepared by adding known amounts of water to weighed portions of the dried simulants. Grinding the mixture with an agate mortar and pestle produced slurries/pastes that appeared homogeneous. Water contents of the prepared simulated waste were verified from the weight loss of the simulants after oven drying overnight at $110^{\circ} \mathrm{C}$.

Near-infrared spectra of the simulated waste (T-Plant, U-Plant, BY-104, SY-101, and InFarm), individual components of the simulated waste, and real mixed waste were taken from $10,000 \mathrm{~cm}^{-1}(1000 \mathrm{~nm})$ to $4000 \mathrm{~cm}^{-1}(2500 \mathrm{~nm})$ with 256 scans at a resolution of $8 \mathrm{~cm}^{-1}$. A single-beam spectrum of $\mathrm{KBr}$ was used as background.

Calibration involved the use of regression mathematics to fit the water values of the simulant training sets to their NIR spectra. Spectra from $7500 \mathrm{~cm}^{-1}$ to $4500 \mathrm{~cm}^{-1}$ containing the first overtone $\left(6900 \mathrm{~cm}^{-1}\right)$ and combination $\left(5150 \mathrm{~cm}^{-1}\right)$ bands of water were used for the spectral analysis. A commercial partial least squares (PLS) package fully integrated with the FTS $60 A$ FTIR system was utilized to calculate water values.

\subsection{MODULAR TRANSFER OPTIC SYSTEM}

In seeking a strategy to identify individual species in the waste with minimal sample preparation, a modular transfer optic system equipped with mid-infrared (MIR) diffuse reflectance accessory was assessed. Light pipes were used to present the sample to the FTIR spectrometer.

Fiber optic probes are potentially the most attractive means to communicate between the FTIR spectrometer and the sample. However, available MIR fibers exhibit fundamental absorption in the fingerprint region and are not resistant to high gamma radiation fields. Nevertheless, MIR spectra offer attractive benefits in the form of distinct and meaningful bands, robust and straightforward calibration, proven diagnostic capability, and insensitivity to spectral artifacts.

The modular transfer optic configuration is displayed in Figure 2. Communication between the FTIR spectrometer (FT2000, Perkin Elmer, Norwalk, CT) and the diffuse reflectance accessory (DR) is accomplished by using a series of hollow metallic light pipes (AXIOM System, AXIOM Analytical, Irvine, CA). The light guide approach is easier to implement and more economical. It is also completely adjustment-free. The detector's optical geometry uses a simple lens to focus the infrared radiation emerging from the light guide onto the infrared detector (liquid nitrogen-cooled MCT). The focusing element is a $90^{\circ}$ off-axis reflecting paraboloid. 
Figure 2. Modular Transfer Optic Configuration

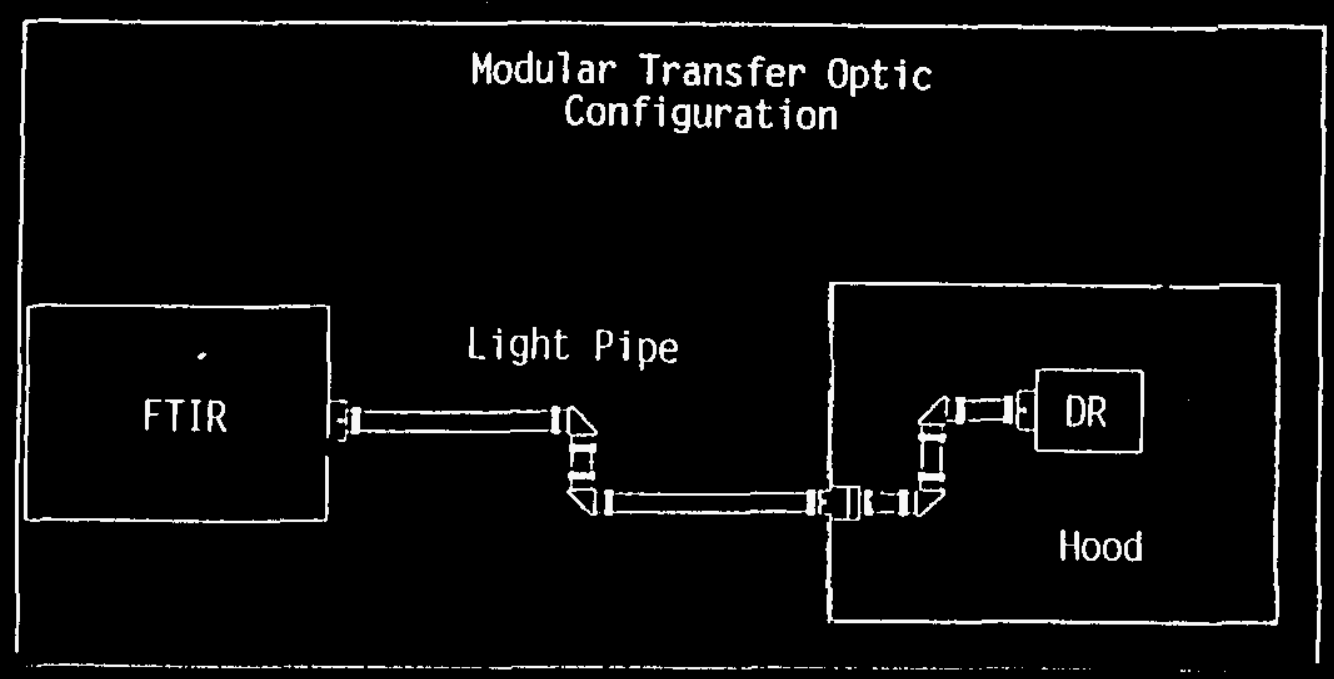

The diffuse reflectance accessory (DR) consists of a pair of off-axis parabolic reflectors (paraboloids) mounted in a rigid structure with their focal points at a common location on the sample. Since a collimated beam is used, infrared radiation traveling parallel to the beam axis is free of optical aberration. Placing the paraboloids at right angles with each other compensates for any possible aberration that occurs for off-axis radiation.

The structure supporting the two paraboloids is free to rotate as a unit around the axis of the incident beam, allowing the angle of incidence to be varied. For a highly diffuse sample, the DR unit can be directed vertically downward; if partly specular, the direction of incidence can be rotated appropriately to eliminate the specular component. The unit can be pointed vertically upward for completely specular reflecting samples. Thus, the DR unit can be used for characterizing both diffuse- and specular-reflecting samples.

Spectral measurements were made from $5000 \mathrm{~cm}^{-1}$ to $600 \mathrm{~cm}^{-1}$ at a resolution of $8 \mathrm{~cm}^{-1}$ using an MCT detector. The spectral resolution was chosen as a compromise between a reasonable spectral resolution to separate and recognize different spectral features and a resolution that gives at the same time a relatively high time resolution of the measurement. Samples were placed in quick change teflon cups or in small stainless steel pans. The infrared beam was focused at the center of the sample with a spot size of $1 \mathrm{~mm}$ and a lalf-aperture angle of 7.5 degrees. In all cases, the samples were examined neat with no particle size reduction. The sample spectra were ratioed against a $\mathrm{KBr}$ spectrum (diffuse reflection) or aluminum mirror (specular reflection) collected under the same condition as those of the samples and transform into diffuse absorbance format. It should be emphasized that this was just an initial exploratory evaluation to determine the modular transfer system's usefulness to collect the MIR spectra of high-level mixed waste. Diffuse reflectance spectra are sensitive to particle size distribution, water content, and sample packing. 


\subsection{RESULTS AND DISCUSSION}

\subsection{SPECTRA OF INDIVIDUAL COMPONENTS OF WASTE}

The NIR spectra of the major inorganic components of the waste (simulated or real) collected by the AXIOM fiber optic probe assembly are displayed in Figures 3 through 6 . Except for disodiummononickel ferrocyanide $\left[\mathrm{Na}_{2} \mathrm{NiFe}(\mathrm{CN})_{6}\right]$, all chemicals were analytical or spectroscopy grade and used "as received". The $\mathrm{Na}_{2} \mathrm{NiFe}(\mathrm{CN})_{6}$ was prepared in the laboratory and dried prior to use. All sample spectra were ratioed to the spectrum of $\mathrm{KBr}$ and transformed to diffuse absorbance plots.

The FTS 60A FTIR spectrometer interfaced to sensitive detectors such as MCT and InSb made possible the use of low-energy throughput diffuse reflectance spectroscopy to record the NIR spectra of the individual components of the waste. Slight absorption is discerned in the region from $5500 \mathrm{~cm}^{-1}$ to $4500 \mathrm{~cm}^{-1}$ for sodium salts. The spectra indicate that $\mathrm{NaNO}_{3}$, $\mathrm{CsNO}_{3}, \mathrm{NaNO}_{2}, \mathrm{Na}_{2} \mathrm{CO}_{3}$ (Figure 3), $\mathrm{NaCl}$, and $\mathrm{NaF}$ (Figure 4) are poor absorbers (absorbance $<0.05$ ) in the NIR region. Sodium chloride $(\mathrm{NaCl})$, for example, is an infrared-transparent material having no known absorption band in the NIR and MIR regions. However, in the solid state, the infrared radiation is transmitted from one particle to the other by total reflectance at contact between particles. It is believed that the lateral diffusion may be responsible for some energy loss which appears as an absorption in the $\mathrm{NaCl}$ spectrum as well as those of the other sodium salts. When these salts are dissolved in water, they are capable of modifying the NIR spectrum of water in a characteristic and measurable way.

Cursory examination of the spectra in Figures 4 through 6 indicates that the most visually accessible information region for the other components of the waste occurs from $7500 \mathrm{~cm}^{-1}$ to $4000 \mathrm{~cm}^{-1}$. A substantial part of the signal in this region is not a result of absorption but of scattering. The tilting of baselines at either higher or lower frequencies is caused by scattering.

Sodium aluminate $\left(\mathrm{NaAlO}_{2}\right)$ and $\mathrm{NaOH}$ (Figure 4) exhibit weak absorption bands in the region where the first overtone of the $\mathrm{OH}$ stretching vibration occurs. On the other hand, $\mathrm{NaCN}$ has multiple weak bands covering the entire water absorption range $\left(6345 \mathrm{~cm}^{-1}\right.$, $5532 \mathrm{~cm}^{-1}, 5102 \mathrm{~cm}^{-1}$, and $\left.4874 \mathrm{~cm}^{-1}\right)$.

Two broad bands from the first overtone of the $\mathrm{OH}$ stretching vibration at $6900 \mathrm{~cm}^{-1}$ and the combination of the $\mathrm{OH}$ stretching and $\mathrm{OH}$ bending vibrations at $5150 \mathrm{~cm}^{-1}$ are the dominant features of hydrates [Figure 5: $\mathrm{Na}_{4} \mathrm{Fe}(\mathrm{CN})_{6} \cdot 10 \mathrm{H}_{2} \mathrm{O}, \mathrm{Ni}_{2} \mathrm{Fe}(\mathrm{CN})_{6} \cdot \mathrm{xH}_{2} \mathrm{O}$ and Figure 6: $\mathrm{Fe}\left(\mathrm{NH}_{4}\right)_{2}\left(\mathrm{SO}_{4}\right)_{2} \cdot \mathrm{H}_{2} \mathrm{O}, \mathrm{NiSO}_{4} \cdot 6 \mathrm{H}_{2} \mathrm{O}$, and $\mathrm{Na}_{3} \mathrm{PO}_{4} \cdot 10 \mathrm{H}_{2} \mathrm{O}$. These bands tend to be weak and broadly overlapping making it impossible to single out other bands in the sample spectra. This necessitates the use of fairly sophisticated software to correlate the observed spectra with the concentration of the other species in the sample. 
WHC-SD-WM-RPT-192 Rev. 0

Figure 3. NIR Reference Spectra

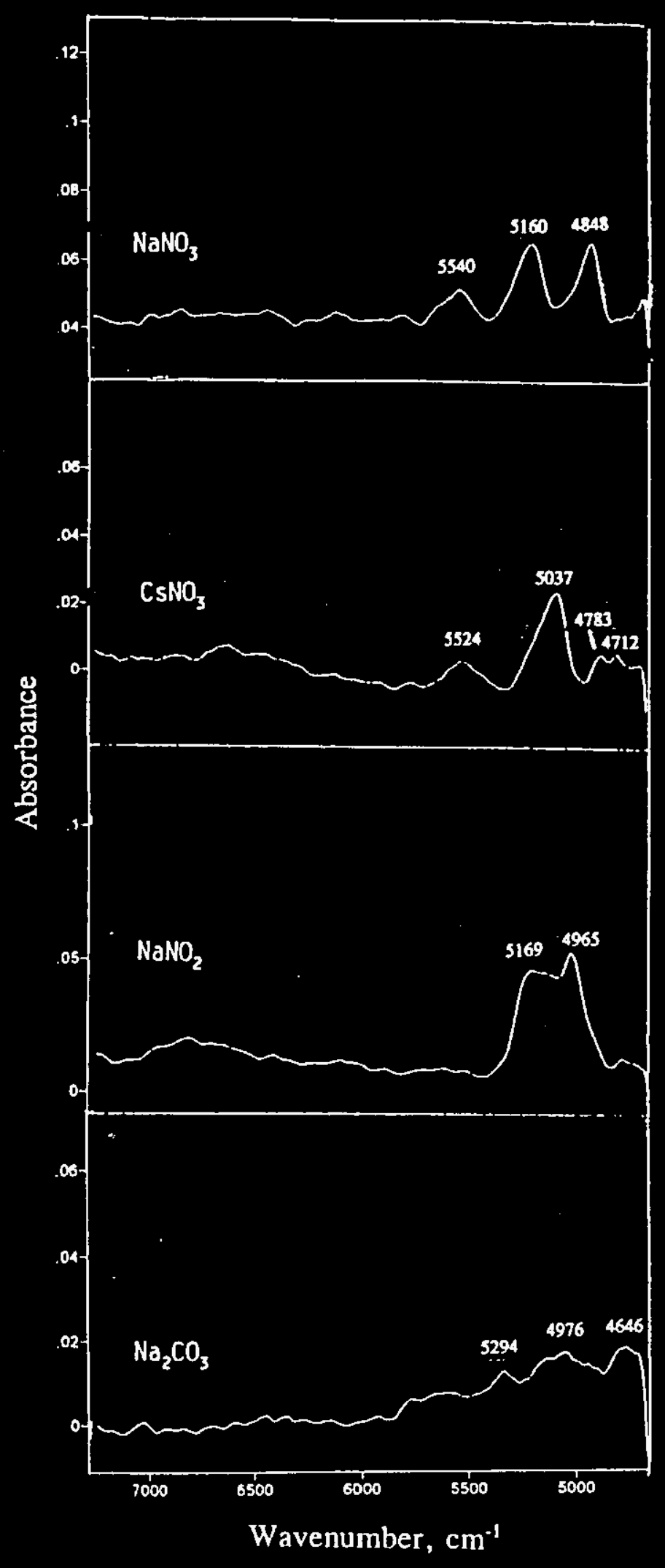


WHC-SD-WM-RPT-192 Rev. 0

Figure 4. NIR Reference Spectra

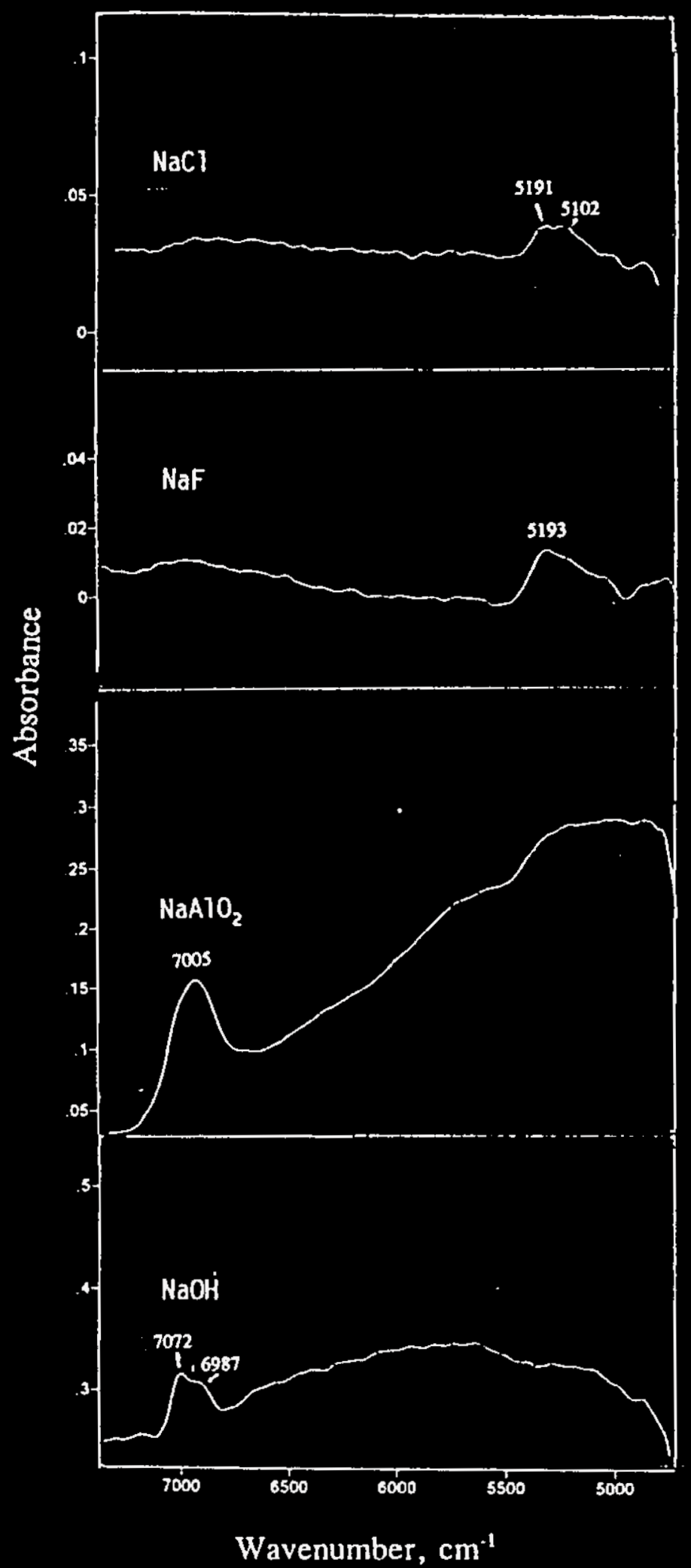


WHC-SD-WM-RPT-192 Rev. 0

Figure 5. NIR Reference Spectra

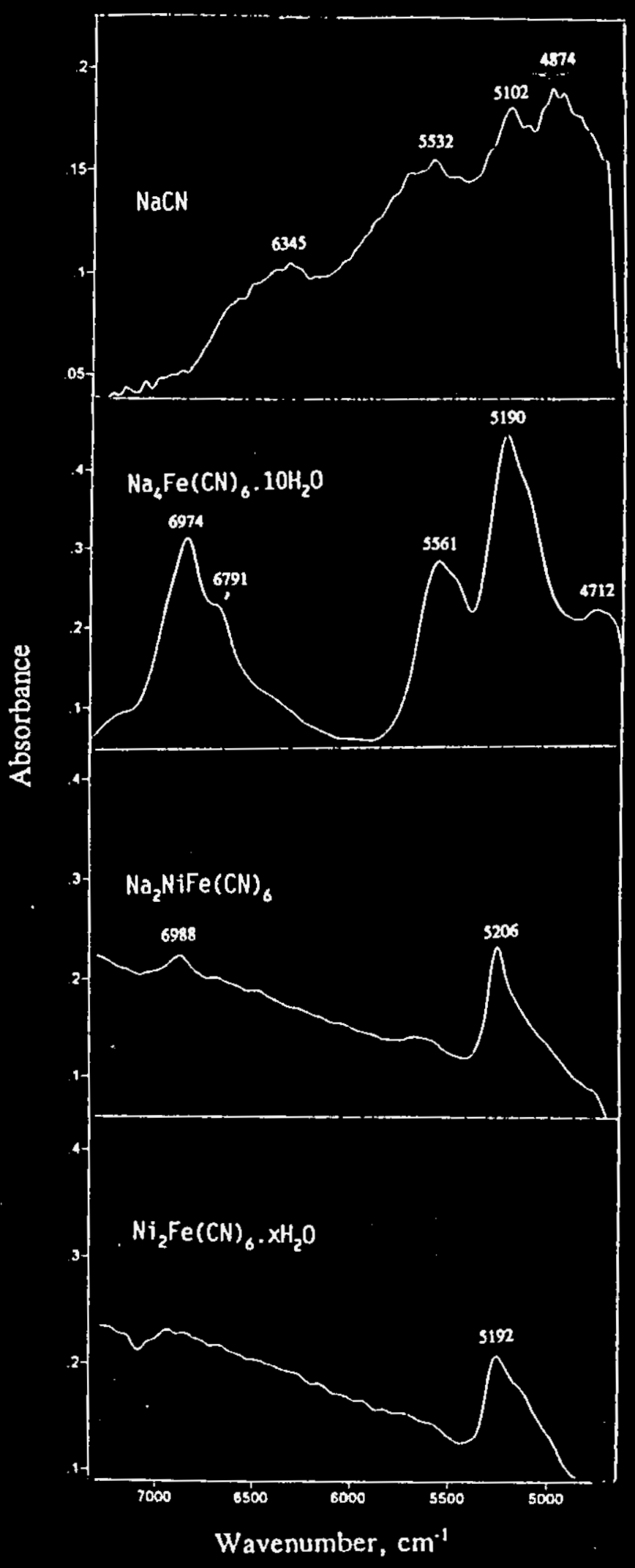


WHC-SD-WM-RPT-192 Rev. 0

Figure 6. NIR Reference Spectra

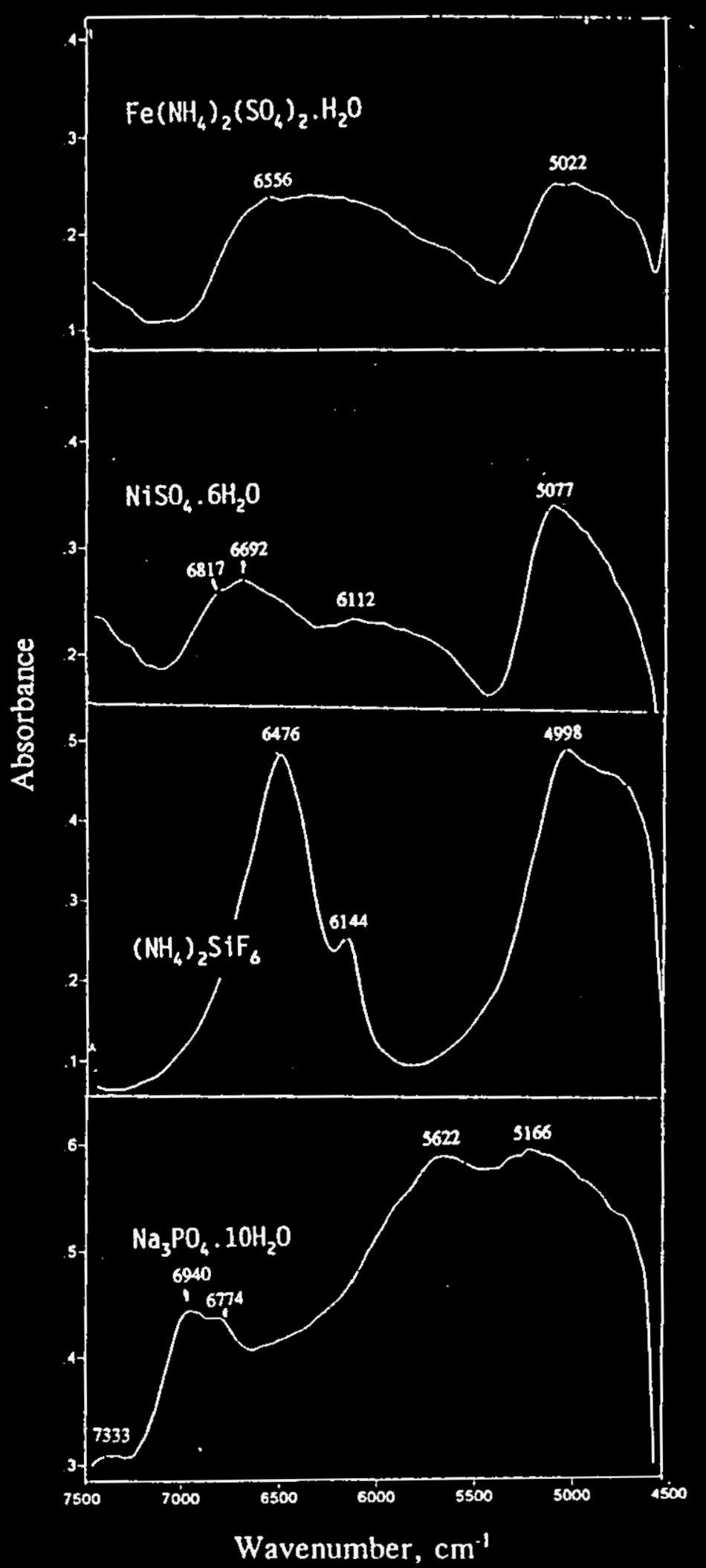


Absorption in the NIR region can be used for the identification of organic compounds through the $\mathrm{CH}, \mathrm{OH}$, and $\mathrm{NH}$ overtone vibrations. Sensitivity can greatly be improved by separating the organic compounds from water which absorbs very intensely in this region. Figure 7 displays the NIR spectra of tributyl phosphate (TBP), n-paraffin hydrocarbon (NPH) and ethylenediaminetetraacetic acid tetrasodium salt trihydrate $\left(\mathrm{Na}_{4}\right.$ EDTA $\left.\cdot 3 \mathrm{H}_{2} \mathrm{O}\right)$. The first overtones of the $\mathrm{CH}_{3}$ - and $\mathrm{CH}_{2}$ - stretching vibrations are strongest at $5900 \mathrm{~cm}^{-1}$ and $5700 \mathrm{~cm}^{-1}$ with weaker combination bands at $7200 \mathrm{~cm}^{-1}$. Their second overtones appear at $8400 \mathrm{~cm}^{-1}$. The band at $6726 \mathrm{~cm}^{-1}$ may be cause by the first overtone of the NH stretching vibration.

\subsection{QUANTITATIVE DETERMINATION OF MOISTURE}

The most pressing concern in performing quantitative spectral measurements using the WSRC probe is the difficulty of obtaining reproducible data because of the small field of view (about $1 \mathrm{~mm}$ compared to $2.3 \mathrm{~mm}$ for the AXIOM probe) and inhomogeneous sample surfaces. Reflectance geometries proved to be prone to noise from surface inhomogeneities. Subtle spectral variations occurred on sets of four (4) replicate measurements taken from different locations in the same sample for each of the simulant examined. These variations included the appearance of weak interference fringes superimposed on the sample spectra. From quantitation standpoint, these fringes increase noise of the spectral data, thus degrading the performance prediction of moisture using the PLS software. For this reason, the AXIOM fiber optic probe, which is more insensitive to spectral variations, was the fiber probe of choice for the quantitative measurement of water in mixed waste. All moisture determinations involving high-level mixed waste were conducted in a hot cell.

Lower absorptivities in the NIR region enabled longer pathlengths to be used leading to easier nondestructive sampling. The full sample spectrum from $7500 \mathrm{~cm}^{-1}$ to $4500 \mathrm{~cm}^{-1}$ was utilized for the calibration and prediction of moisture contents. Both overtone and combination bands of water were used to monitor water contents of the samples.

The results of the PLS validation of the AXIOM fiber optic probe using real high-level radioactive mixed waste are summarized in Table 1 . The calibration model was tested using raw and smoothed mixed waste spectra. The standard error of prediction (SEP) is 8.35. Table 1 indicates that no advantage is gained by smoothing the spectra. Perhaps the addition of more water standards to the calibration set will improve prediction of water making the PLS model applicable to all Hanford mixed waste. Work is continuing to improve the performance of the method.

Typical spectra of mixed waste with low moisture contents are displayed in Figure 8 . Semidried waste are characterized by the presence of small bands in the $7000 \mathrm{~cm}^{-1}$ region (first overtone of the $\mathrm{OH}$ stretch). Partial dissolution of the waste results in changes in peak shapes, notably the disappearance of these small bands in the $7000 \mathrm{~cm}^{-1}$ region as depicted in the spectra of wet samples (Figure 9). It is evident that the small bands are caused by combined water, possibly, hydrates. Broadening of the band is indicative of more free 
WHC-SD-WM-RPT-192 Rev. 0

Figure 7. NIR Reference Spectra for Three Organic Compounds

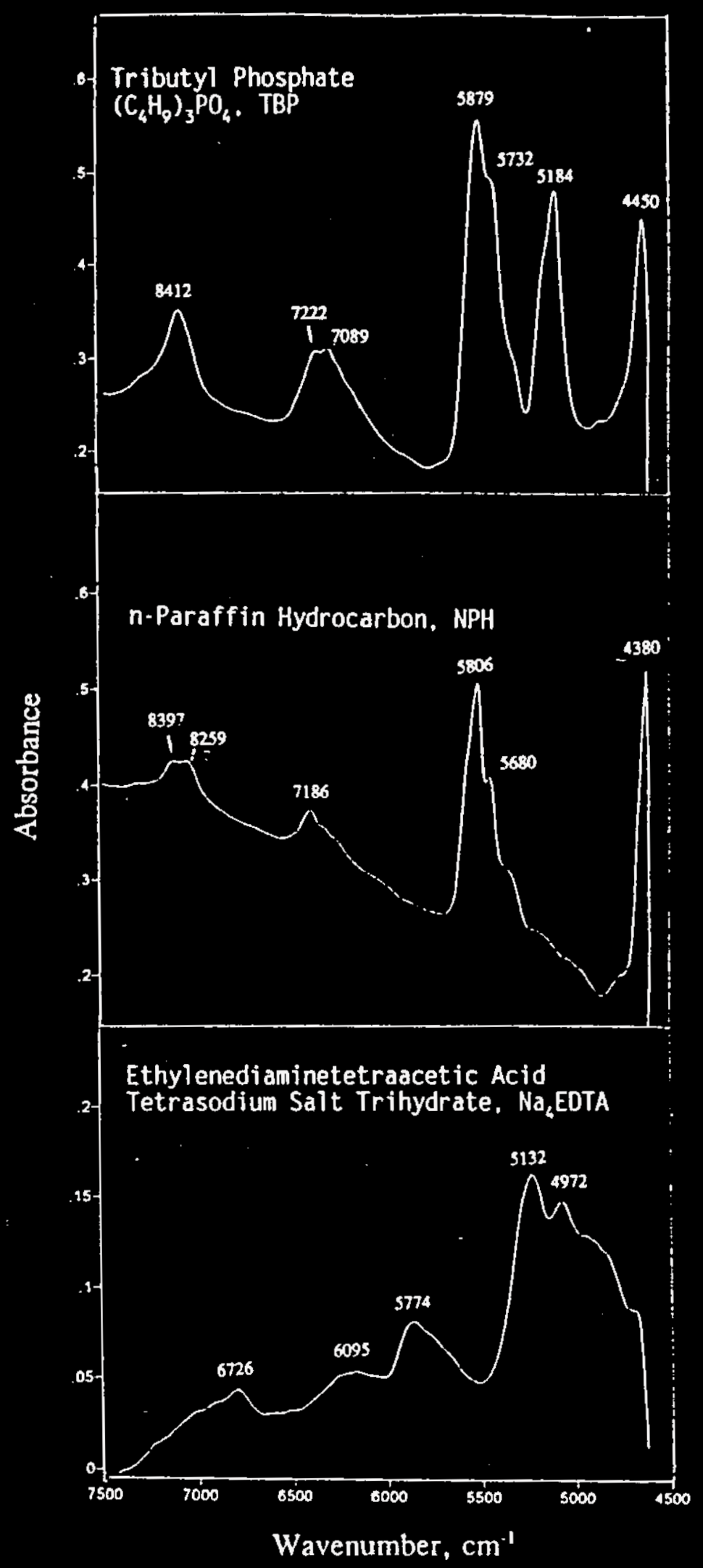


Table 1. Standard Error of Prediction Results

\section{Partial Least Squares Calibration}

\begin{tabular}{|c|c|c|}
\hline \multicolumn{3}{|c|}{$\begin{array}{l}\text { Smoothed, Mean-Centered 0-35wt\% } \\
\text { Simulant Data Set Using 10-Factor PLS } \\
\text { Model }\end{array}$} \\
\hline Predicted & Actual & Error \\
\hline 18.09 & 16.3 & 1.79 \\
\hline 15.78 & 16.3 & -0.52 \\
\hline 16.21 & 16.3 & -0.09 \\
\hline 32.24 & 26.3 & 5.94 \\
\hline 30.66 & 26.3 & 4.36 \\
\hline 31.69 & 26.3 & 5.39 \\
\hline 17.19 & 18 & -0.81 \\
\hline 17.74 & 18 & -0.26 \\
\hline 14.85 & 18 & -3.15 \\
\hline 26.7 & 13.3 & 13.4 \\
\hline 30.66 & 13.3 & 17.36 \\
\hline 30.44 & 13.3 & 17.14 \\
\hline 11.47 & 25.8 & -14.33 \\
\hline 21.98 & 25.8 & -3.82 \\
\hline 25.35 & 25.8 & -0.45 \\
\hline \multicolumn{2}{|c|}{ Standard Prediction Error } & 8.35 \\
\hline
\end{tabular}

\begin{tabular}{|c|c|c|}
\hline \multicolumn{3}{|c|}{$\begin{array}{l}\text { Raw, Mean-Centered, 0-35\% Simulant Data } \\
\text { Set with } 7500 \mathrm{~cm}^{-1} \text { Shifted to } 0.0 \text { Using a 9- } \\
\text { Factor PLS Model }\end{array}$} \\
\hline Predicted & Actual & Error \\
\hline 30.37 & 16.3 & 14.07 \\
\hline 26.98 & 16.3 & 10.68 \\
\hline 24.85 & 16.3 & 8.55 \\
\hline 41.12 & 26.3 & 14.82 \\
\hline 42.22 & 26.3 & 15.92 \\
\hline 42.87 & 26.3 & 16.57 \\
\hline 27.67 & 18 & 9.67 \\
\hline 27.91 & 18 & 9.91 \\
\hline 25.34 & 18 & 7.34 \\
\hline 41.34 & 13.3 & 28.04 \\
\hline 39.6 & 13.3 & 26.3 \\
\hline 36.49 & 13.3 & 23.19 \\
\hline 23.73 & 25.8 &.-2.07 \\
\hline 29.19 & 25.8 & 3.39 \\
\hline 32.14 & 25.8 & 6.34 \\
\hline \multicolumn{2}{|c|}{ Standard Prediction Error } & 8.34 \\
\hline
\end{tabular}


WHC-SD-WM-RPT-192 Rev. 0

Figure 8. Spectra of Tank Waste with Low Moisture Content

\section{Spectra of Tank Wastes with Low Moisture Content}
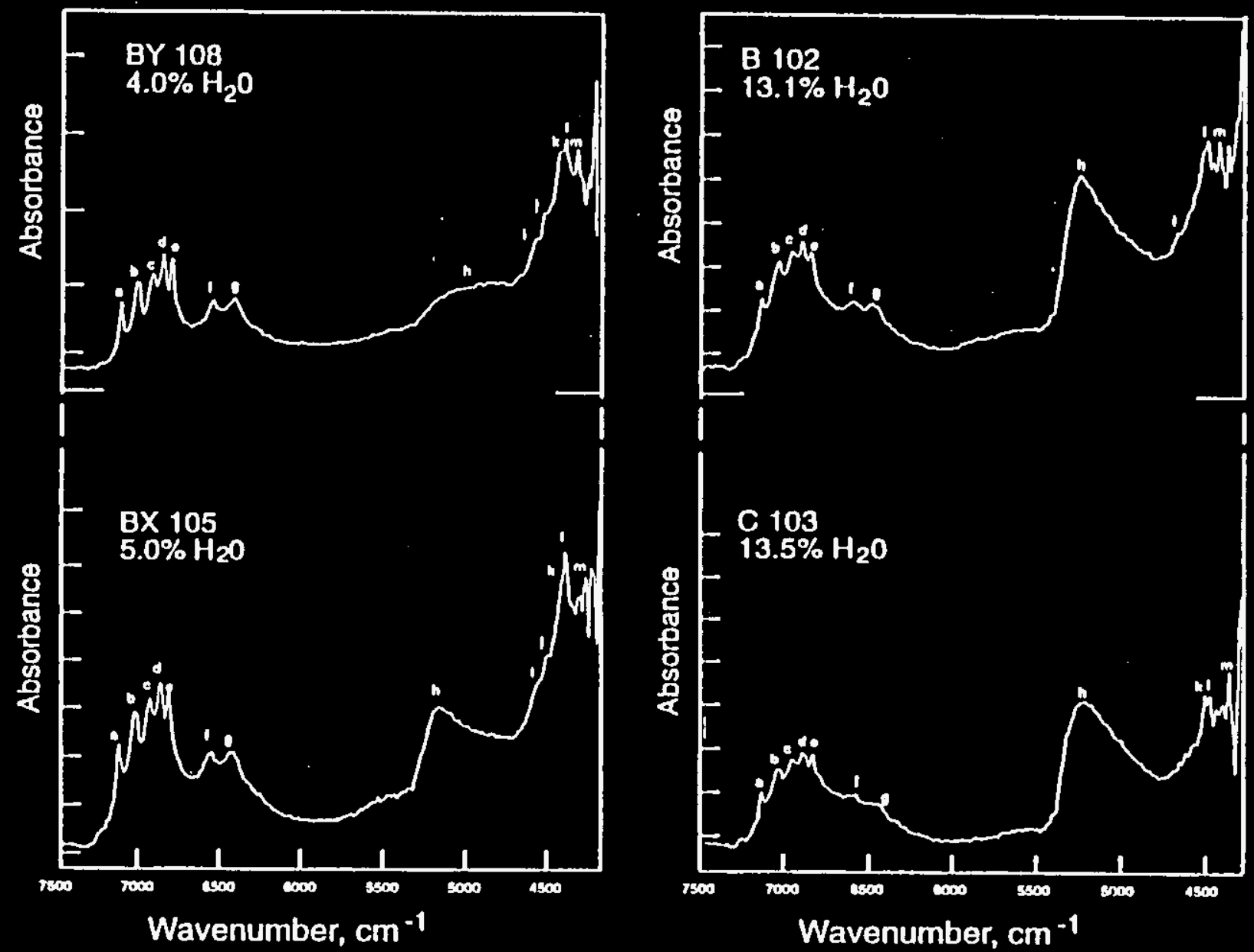
a. 7149
e. 6843
J. 4520
b. 7051
1. 6586
k. 4415
c. 6957
g. 6482
I. 4404
d. 6895
h. $\mathbf{5 2 5 0}$
m. 4341
i. 4570

29506055. 1 
Figure 9. Spectra of Tank Waste with High Moisture Content
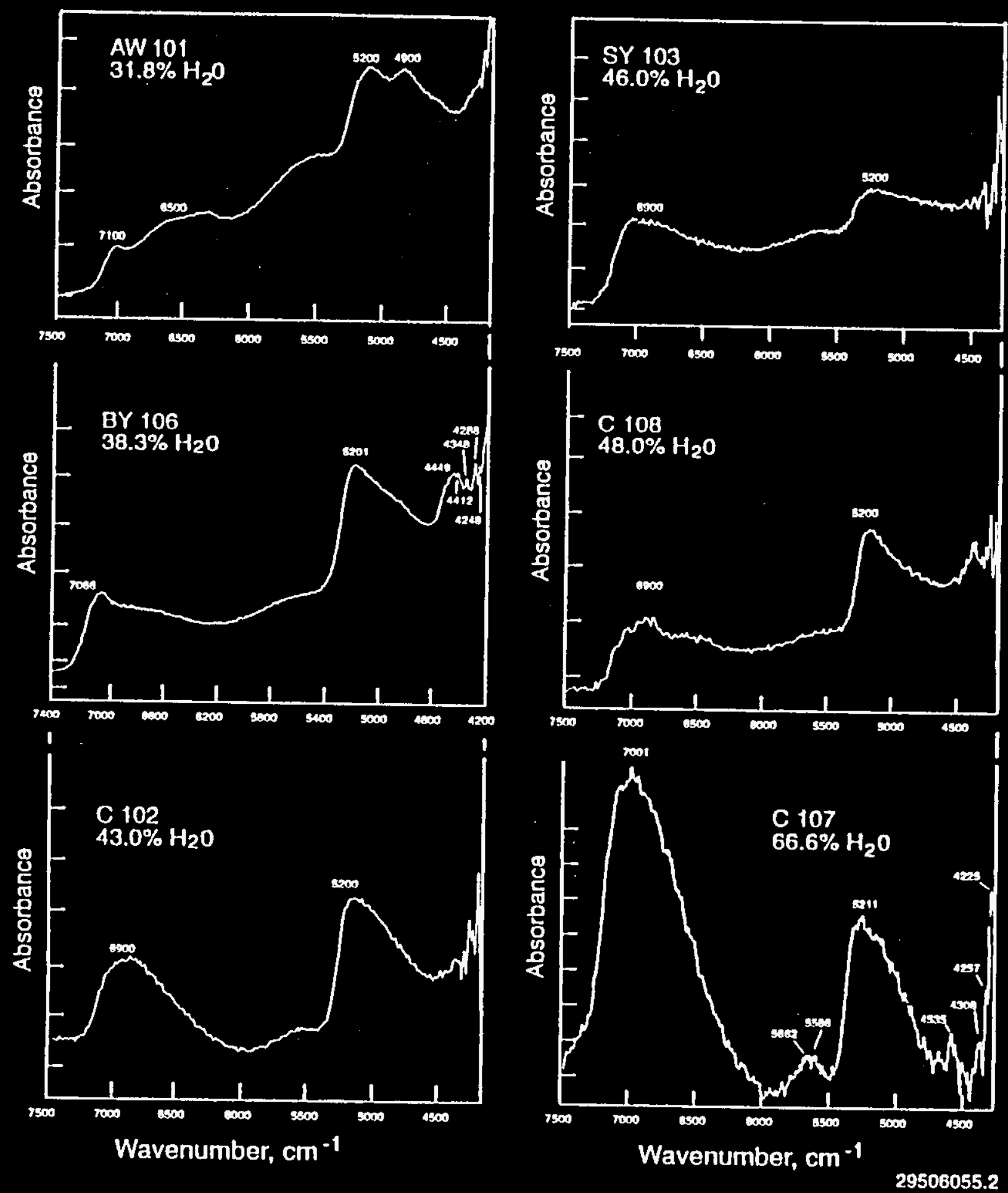
water in the sample. It is often difficult to acquire good spectra of wet core samples (Figure 9), particularly, those of jelly-like consistencies. However, the dominant features of all of these spectra are the overtone and combination bands of water.

\subsection{MIR CHARACTERIZATION}

This phase of the study deals primarily with qualitative analysis and species identification. Diffuse reflectance spectroscopy monitors the characteristics of the bulk sample and is affected by thickness variation and particle size. In general, diffuse reflectance is only usable for quantitative measurement if the sample is ground up and mixed with a transparent scattering matrix (KBr). Additionally, interference fringes (optical interference between light reflected from the front and back surfaces of the sample) resulting from the use of neat samples cannot simply be subtracted from the sample spectrum because they do not depend monotonically on thickness.

Figure 10 shows the diffuse absorbance spectra of two oven-dried simulants, BY-104 and SY-101. These spectra are those of neat samples and are compared with the photoacoustic spectra of aliquots (also neat) of the same simulants but were freeze-dried at $-50^{\circ} \mathrm{C}$ for 6 hours (Figure 11). The diffuse reflectance spectra have more distinct bands for chemical structure elucidation than the photoacoustic spectra. However, neat diffuse reflectance spectra are susceptible to distortion near strong absorption bands because of the large changes in the reflectivity (refractive index). These reflectivity changes result in a large specular component that acts in opposition to the diffuse component. With the AXIOM diffuse reflectance unit of the modular transfer optic system, the specular component may be eliminated as described in the experimental section. This capability of the AXIOM diffuse reflectance unit needs to be addressed in future work on characterization of organics in mixed waste.

The photoacoustic spectra in Figure 11 demonstrate the difficulty of interpreting and quantifying saturated photoacoustic bands. For example, the nitrate content cannot be monitored quantitatively via the nitrate band at $1363 \mathrm{~cm}^{-1}$. Like diffuse reflectance spectroscopy, photoacoustic spectroscopy depends on weak bands for quantitation of species of interest. The photoacoustic technique may be an alternative approach to quantitation but this technique cannot be utilized without prior removal of water.

Application of the MIR modular transfer optic technique to characterize high-level radioactive mixed waste (tank $\mathrm{C}-107$ ) is demonstrated in Figures 12a and 12b. It appears that this technique can be used to measure moisture content in mixed waste remotely. The spectral region from $3700 \mathrm{~cm}^{-1}$ to $1500 \mathrm{~cm}^{-1}$ may be utilized for PLS spectral treatment. This region contains the $\mathrm{OH}$ stretching $\left(3400 \mathrm{~cm}^{-1}\right)$ and bending $\left(1620 \mathrm{~cm}^{-1}\right)$ vibration bands of water. The reliability of this technique to predict water contents can be compared with its PLS NIR counterpart described earlier. 
WHC-SD-WM-RPT-192 Rev. 0

Figure 10. MIR Spectra of BY-104 and SY-101 Waste

Simulants (Modular Transfer Optics Method)
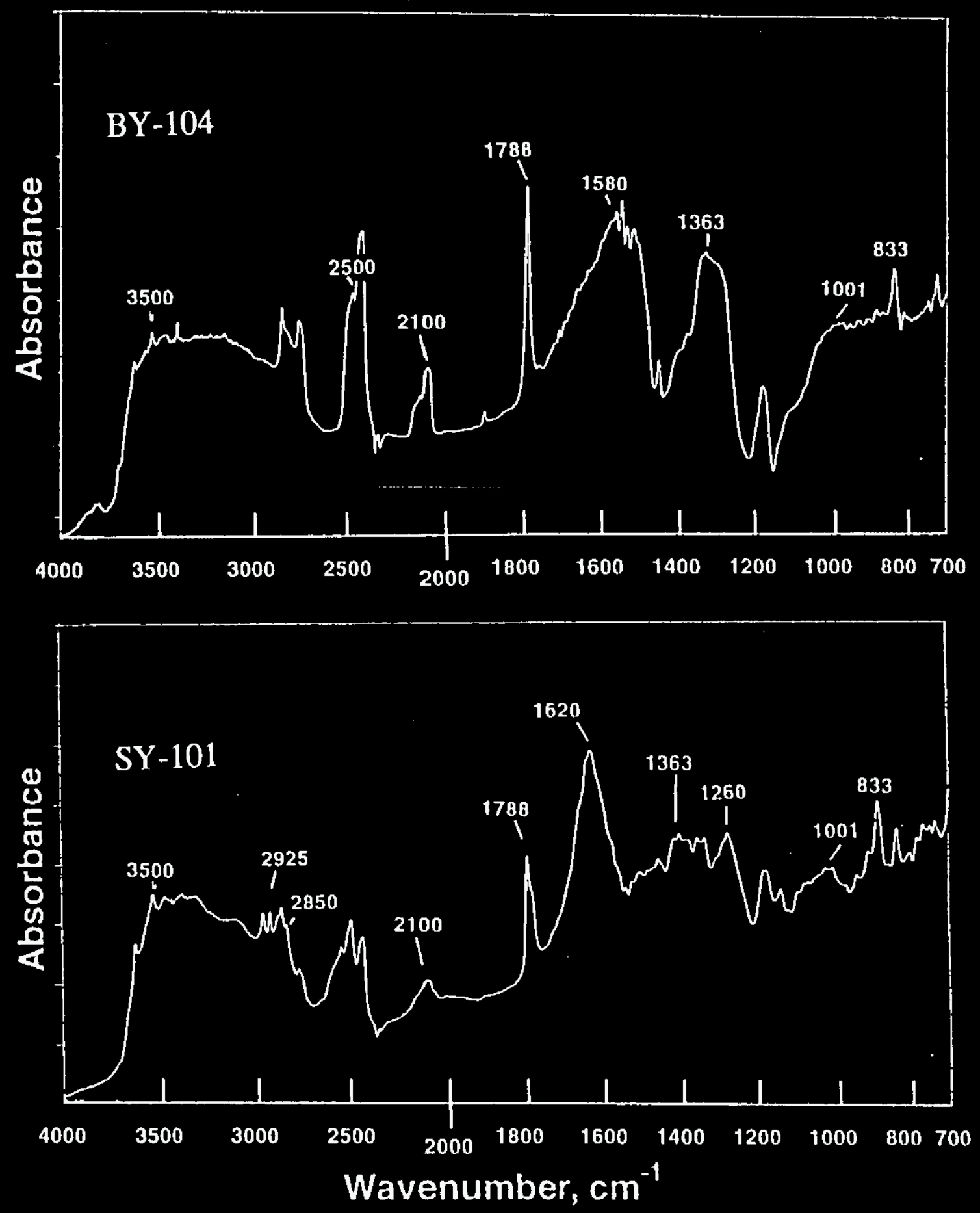
WHC-SD-WM-RPT-192 Rev. 0

Figure 11. MIR Spectra of BY-104 and SY-101 Waste Simulants (Photoacoustic Method)
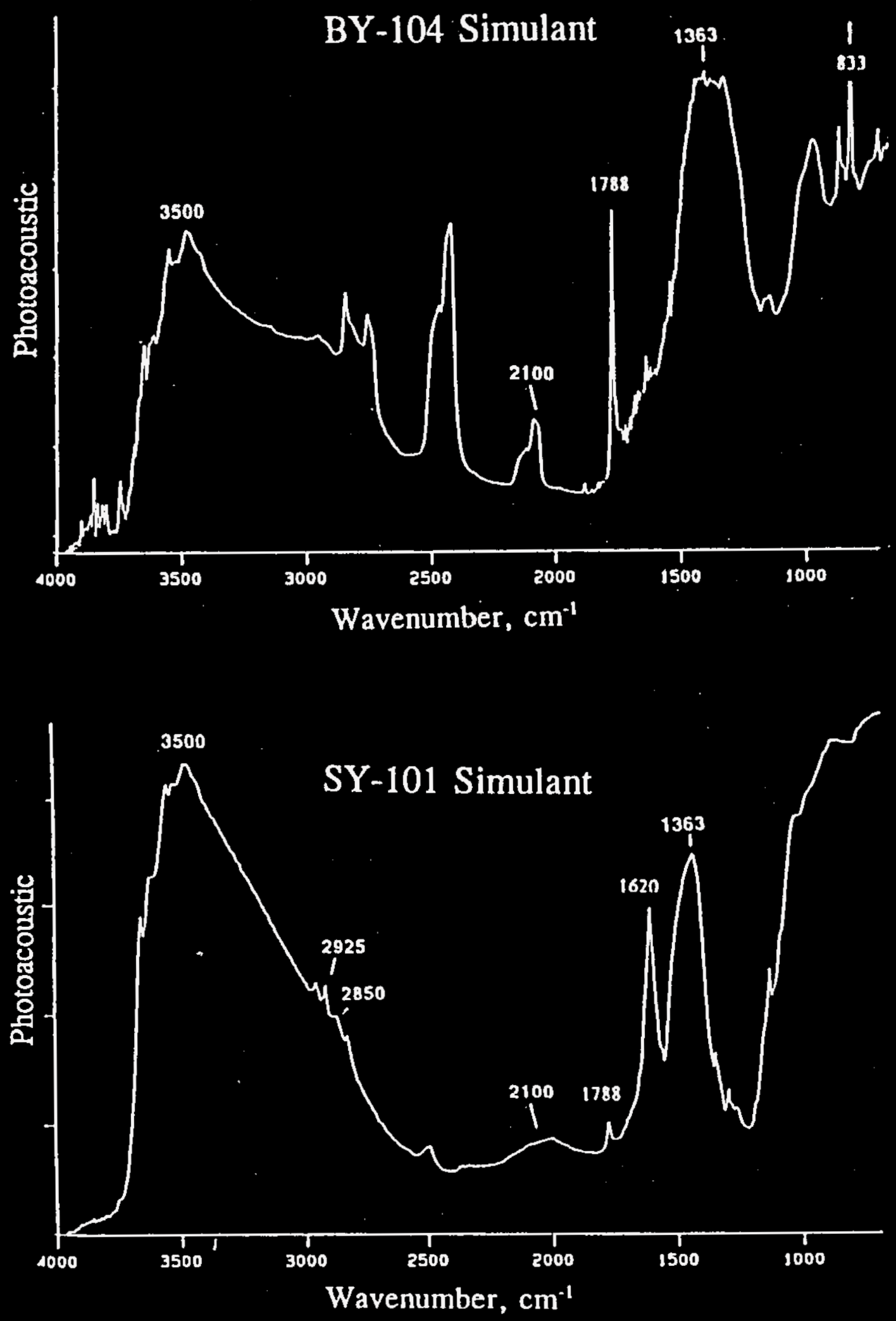
Figure 12. Spectra of Tank C-107 Waste
a. MIR Spectrum (As Received)
c. NIR Spectrum (As Received)
b. MIR Spectrum (Freeze Dried)
d. NIR Spectrum (Freeze Dried)
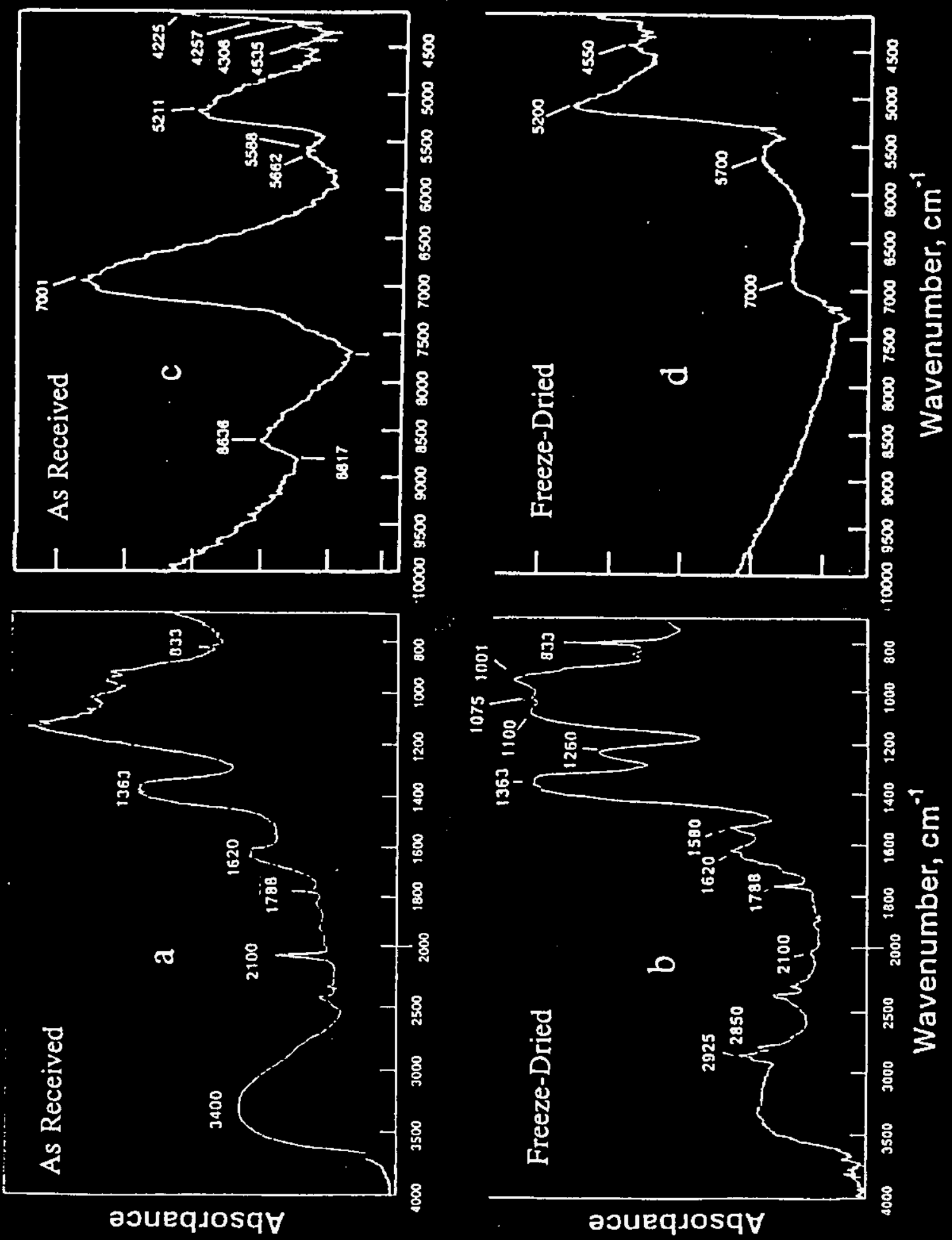
A comparison of the MIR spectrum of the freeze-dried C-107 sample with its NIR spectrum (Figure 12b versus Figure 12d) reveals that only water can be determined in the NIR region. In contrast, organics, nitrates, and nitrites can be quantified in the MIR region making the MIR modular transfer optic system more appropriate for measuring the concentration of fuels and oxidizers in the waste.

\subsection{CONCLUSIONS}

The results of the tests run in FY 1995 confirm the usefulness of simulants to predict and model moisture concentrations of high-level mixed waste using partial least squares multivariate analysis. The complexity of the calibration is considerable but the extreme simplicity of its subsequent use for testing unknown moisture concentrations in mixed waste fully justifies the time spent for calibrating the fiber optic probes. The observed standard error of predicting moisture values is high and needs improvement. Use of mixed waste from additional waste tanks, to reflect the uniqueness of each tank waste in establishing quantitative changes in sample spectra, is recommended. 
WHC-SD-WM-RPT-192 Rev. 0

This page intentionally left blank. 


\subsection{REFERENCES}

Babad, H, J. W. Hunt, and K. S. Redus, 1995, Tank Safety Screening Data Quality Objective, WHC-SD-WM-SP-004, Rev. 1, Westinghouse Hanford Company, Richland, Washington.

Fauske, H. K., M. Epstein, D. R. Dickinson, R. J. Cash, D. A. Turner, and J. E. Meacham, 1995, The Contact-Temperature Ignition (CTI) Criteria for Propagating Chemical Reactions Including the Effect of Moisture and Application to Hanford Waste, WHC-SD-WM-ER-496, Rev. 0, Westinghouse Hanford Company, Richland, Washington.

Jeppson, D. W., and J. J. Wong, 1993, Ferrocyanide Waste Simulant Characterization, WHC-EP-0631, Westinghouse Hanford Company, Richland, Washington.

Rebagay, T. V., R. J. Cash, and J. E. Meacham, 1994, "Evaluation of FTIR-Based Analytical Methods for the Analysis of Hanford Site Waste," accepted for publication in Journal of On-Site Analysis, Northbrook, Illinois.

Rebagay, T. V., R. J. Cash, D. A. Dodd, J. E. Meacham, and C. T. Narquis, 1995, Evaluation of FTIR-Based Analytical Methods for the Analysis of Hanford Site Waste, WHC-SA-2894-FP, Westinghouse Hanford Company, Richland, Washington. 


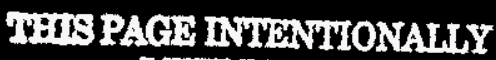
IEATBLANK 